\title{
Effect of abscisic acid on the calcium content for controlling blossom-end rot in tomato under water stress ${ }^{1}$
}

\author{
Carlos Agostinho Balate ${ }^{2}$, Douglas Correa de Souza ${ }^{3}$, \\ Luciane Vilela Resende ${ }^{3}$, Sergio Tonetto de Freitas ${ }^{4}$
}

\section{ABSTRACT}

Water stress in tomato plants may cause the incidence of blossom-end rot. This study aimed to analyze the effect of abscisic acid leaf application for increasing the calcium uptake in irrigated tomato ('Santa Clara' cultivar) in the field, as a possible mechanism of blossom-end rot inhibition. The treatments consisted of four irrigation levels $(25 \%$, $50 \%, 75 \%$ and $100 \%$ of the crop water requirements to fulfil the crop evapotranspiration) and two abscisic acid doses $\left(0 \mathrm{mg} \mathrm{L}^{-1}\right.$ and $\left.500 \mathrm{mg} \mathrm{L}^{-1}\right)$. The fruits were harvested at 15 and 30 days after the anthesis and evaluated for calcium content and percentage of blossom-end rot. The application of abscisic acid increased the calcium partition to the distal region of the fruits at 30 days after the beginning of flowering, as well as reduced the incidence of blossom-end rot by $86 \%$, when compared with plants not treated with abscisic acid. It is possible to conclude that the foliar application of abscisic acid can significantly reduce the incidence of blossom-end rot.

KEYWORKS: Solanum lycopersicum; phytohormones; plant defense mechanism.

\section{INTRODUCTION}

Calcium $(\mathrm{Ca})$ is a plant nutrient required as a structural component in the cell wall and membranes, counter ion in storage organelles and signalling molecule in the cytosol (White 2001). Conditions that restrict the Ca uptake, such as high salinity, excess or lack of moisture, root diseases, high temperatures and low levels of $\mathrm{Ca}$ in the soil, may cause Ca deficiency symptoms in plants (Saure 2014). These symptoms may occur even at ideal levels of $\mathrm{Ca}$ in the soil for the normal plant growth and development (Suzuki et

\section{RESUMO}

Influência do ácido abscísico no conteúdo de cálcio para o controle da podridão apical em tomate sob estresse hídrico

O estresse hídrico no tomate pode causar o aparecimento de podridão apical. Objetivou-se analisar o efeito da aplicação foliar de ácido abscísico no aumento da absorção de cálcio em tomate (cultivar 'Santa Clara') sob irrigação no campo, como um possível mecanismo de inibição da podridão apical. Os tratamentos consistiram de quatro níveis de rega $(25 \%, 50 \%, 75 \%$ e $100 \%$ das necessidades de água para suprir a evapotranspiração da cultura) e duas doses de ácido abscísico $\left(0 \mathrm{mg} \mathrm{L}^{-1}\right.$ e $\left.500 \mathrm{mg} \mathrm{L}^{-1}\right)$. Os frutos foram colhidos aos 15 e 30 dias após a antese e avaliados para a concentração de cálcio e porcentagem de podridão apical. A aplicação de ácido abscísico aumentou a partição de cálcio para a região distal dos frutos aos 30 dias após o início da floração, bem como reduziu a incidência de podridão apical em $86 \%$, quando comparada a plantas sem a aplicação de ácido abscísico. Conclui-se que a aplicação foliar de ácido abscísico pode reduzir significativamente a incidência de podridão apical.

PALAVRAS-CHAVE: Solanum lycopersicum; fito-hormônios; mecanismo de defesa vegetal.

al. 2003). In tomato plants (Solanum lycopersicum), such conditions may lead to a physiological disorder known as blossom-end rot (Suzuki et al. 2003), which is characterized by a water-soaked tissue that eventually becomes dark-brown due to an increase in the membrane permeability, followed by cell plasmolysis and death (Sure 2014).

It is generally accepted that the blossom-end rot occurs due to a lack of $\mathrm{Ca}$ in the distal fruit tissue, during early stages of growth and development. During these stages, fruit growth takes place mainly by cell expansion (Suzuki et al. 2003). It has been

1. Received: Mar. 20, 2018. Accepted: Aug. 20, 2018. Published: Nov. 29, 2018. DOI: 10.1590/1983-40632018v4852048.

2. Instituto Superior Politécnico de Gaza, Chokwé, Gaza, Moçambique.E-mail/ORCID: carlos_balate@yahoo.com.br/ 0000-0002-3185-5146.

3. Universidade Federal de Lavras, Departamento de Agricultura, Lavras, MG, Brasil.

E-mail/ORCID: douglascorrea@ymail.com/0000-0003-3956-1342, luciane.vilela@dag.ufla.br/0000-0002-2014-4453.

4. Empresa Brasileira de Pesquisa Agropecuária (Embrapa Semiárido), Petrolina, PE, Brasil.

E-mail/ORCID: sergio.freitas@embrapa.br/0000-0001-9579-7304. 
suggested that blossom-end rot may occur due to limited fruit $\mathrm{Ca}$ uptake by roots, deficient $\mathrm{Ca}$ translocation in vascular vessels and inadequate $\mathrm{Ca}$ allocation in fruits during a period of high demand. This leads to a dilution of $\mathrm{Ca}$ in the fast expanding fruit tissue (Atkinson 2014).

Water restriction is one of the main causes of deficient Ca uptake by roots (Adams \& Ho 1993). Nevertheless, water management methods can reduce the incidence of blossom-end rot. For example, irrigation deficit is a field technique where plants are irrigated with small amounts of water (Geerts \& Raes 2009), and the plants grow with a reduction of stomatal conductance, but without signs of water stress (Costa et al. 2007).

Plant growth and development are coordinated and controlled by phytohormones. Abscisic acid (ABA) is a stress hormone that regulates the plant life cycle (Cutler et al. 2010). In situations of moderate stress, plant root tissues begin to synthesize the ABA that is released into the xylem vessels and transported to the shoot, where stomata and meristematic activities are regulated to minimize stress (Jiang \& Hartung 2008). Although ABA is synthesized when responding to drought stress, studies demonstrated that the concentration of ABA in the sap from plants in a dry soil is lower than the concentration of exogenous ABA necessary for stomatal closing (Schachtman \& Goodger 2008). Recent studies have shown that ABA triggers whole-plant and fruit-specific mechanisms leading to high fruit $\mathrm{Ca}$ uptake and apoplastic $\mathrm{Ca}$ concentration, reducing the membrane permeability and blossom-end rot incidence in the fruit tissue (Freitas et al. 2011 and 2014, Barickman et al. 2014).

This study tested the hypothesis that tomato plants treated with ABA under water stress increase the Ca uptake and, therefore, prevent the blossomend rot development. Thus, it aimed to analyze the role of $\mathrm{ABA}$ in increasing the $\mathrm{Ca}$ uptake in the fruit tissue, as a possible mechanism of blossom-end rot incidence inhibition, in water stressed tomato plants.

\section{MATERIAL AND METHODS}

The experiment was carried out under field conditions at the Universidade Federal de Lavras, in Lavras, Minas Gerais state, Brazil (21 ${ }^{\circ} 14^{\prime} 16^{\prime}$ 'S, $45^{\circ} 08^{\prime} 00^{\prime \prime} \mathrm{W}$ and $920 \mathrm{~m}$ above the sea level), from February to June 2016. The climate of the region, according to the Köppen climatic classification, is Cwa (mesothermal), with dry winters and rainy summers (Brasil 1992).

Tomato seeds of the 'Santa Clara' cultivar were sown in a 78-cell plastic tray and germinated in a protected environment (non-heated greenhouse). At 35 days after sowing, the plants were transplanted to the field.

The soil chemical and physical analysis showed $\mathrm{pH}\left(\mathrm{CaCl}_{2}\right)=5.4 ; \mathrm{K}^{+}=70 \mathrm{mg} \mathrm{dm}{ }^{-3} ; \mathrm{P}=2.91 \mathrm{mg} \mathrm{dm}^{-3}$; P-Rem $=27.41 \mathrm{mg} \mathrm{L}^{-1} ; \mathrm{Ca}^{+2}=2.12 \mathrm{cmol} \mathrm{dm}^{-3}$; $\mathrm{Mg}^{+2}=0.74 \mathrm{cmol} \mathrm{dm}^{-3} ; \mathrm{OM}=1.64 \mathrm{dag} \mathrm{kg}^{-1} ; \mathrm{H}+\mathrm{Al}=$ $3.35 \mathrm{cmol} \mathrm{dm}^{-3} ; \mathrm{SB}=3.04 \mathrm{cmol} \mathrm{dm}^{-3} ; \mathrm{V}=47.6 \%$; sand $=46 \%$; clay $=36 \%$; and silt $=18 \%$. According to the soil analyses, $600 \mathrm{~kg} \mathrm{ha}^{-1}$ of NPK (4:14:8) were applied before transplanting, as well as $1 \mathrm{~kg} \mathrm{ha}^{-1}$ of $\mathrm{B}, 3 \mathrm{~kg} \mathrm{ha}^{-1}$ of $\mathrm{Zn}$ and $30 \mathrm{~kg} \mathrm{ha}^{-1}$ of S.

After transplanting, each plant was fertilized with $4.5 \mathrm{~g}$ of monoammonium phosphate (50\%), $\mathrm{KNO}_{3}(40 \%)$ and urea $(10 \%)$, from the first to the fourth week; $4 \mathrm{~g}$ of monoammonium phosphate $(20 \%), \mathrm{KNO}_{3}(70 \%)$ and urea $(10 \%)$, from the fifth to the eighth week; and $4 \mathrm{~g}$ of $\mathrm{KNO}_{3}(85 \%)$ and urea $(15 \%)$, from the ninth week onwards. No $\mathrm{Ca}$ was added in order to stimulate the blossom-end rot incidence, because the Ca concentration in the soil was considered as the minimum required for a normal plant growth. The fertilization program followed soil recommendations for the Minas Gerais state (Gomes et al. 1999).

At 15 days after transplanting (DAT), plants were treated with deltametrina, acephate, triflumuron and thiamethoxam, for pest management, following the necessary recommendations. At 45, 60 and 75 DAT, plants were treated with azoxystrobin and iprodione, for disease management. During the experiment, from the anthesis to harvest, the total precipitation was $22.2 \mathrm{~mm}$, the average crop evapotranspiration (ETc) was $5 \mathrm{~mm} \mathrm{day}^{-1}$, and the average temperatures were $18.8^{\circ} \mathrm{C}$ (minimum) and $30.2{ }^{\circ} \mathrm{C}$ (maximum).

Plots were allocated in a complete randomized block design, with 8 treatments and 4 replications. The treatments consisted of four water supply levels: $25 \%, 50 \%, 75 \%$ and $100 \%$ of the crop water requirements, as indicated by the water necessary to fulfil the ETc restoration. Each plot consisted of 5 plants. Plants were treated weekly with $0 \mathrm{mg} \mathrm{L}^{-1}$ (deionised water) or $500 \mathrm{mg} \mathrm{L}^{-1}$ of ABA (Valent BioScienes, Inc., Libertyville, IL, USA) through 
foliar spray application. The $100 \%$ of ETc and deionised water were set as a control treatments. The concentration of $500 \mathrm{mgL}^{-1}$ of ABA was chosen based on Astacio \& Van Iersel (2011).

The ABA was sprayed until the foliage was wet and dripping. A plastic bag was placed under the plants to avoid the solution to reach the soil. A drip irrigation system was used and irrigation treatments were applied following the evapotranspiration method based on changes in the water balance $(\mathrm{ETc}=\mathrm{ETo} \times \mathrm{Kc})$. The ETc was calculated by means of a Class A evaporimetric tank and Kc according to Doorenbos \& Pruitt (1977). Plants were watered equally from the plant establishment to the beginning of anthesis. The ABA and deionised water treatments started at anthesis and were applied up to the harvest.

The $\mathrm{Ca}$ concentration was determined in 5 health fruits per plot (without any visible blossomend rot symptom) that were harvested at 15 and at 30 days after the anthesis (DAA). Fruit discs of approximately $1.0 \mathrm{~cm}$ in diameter and $1.0 \mathrm{~cm}$ in thickness were manually cut from the fruit blossom end tissue. Fruits were then dried in a forced dry oven at $60{ }^{\circ} \mathrm{C}$, for $72 \mathrm{~h}$. Fully expanded leaves at midplant height were collected at 15 DAA and dried in a forced dry oven at $60^{\circ} \mathrm{C}$, for $72 \mathrm{~h}$. Samples of fruits and leaves dry mass were subjected to block acid digestion. The concentration of $\mathrm{Ca}$ was determined by atomic absorption spectrophotometry.

The percentage of blossom-end rot incidence was determined by dividing the number of fruits with blossom-end rot symptoms by the total number of fruits collected per plant, and multiplying this value by 100 .

The data were evaluated by analysis of variance (Anova) for each variable, using the $R$ software. Linear regressions were established between the ETc and the percentage of blossomend rot incidence. The mean treatment values were compared by the Scott-Knott test $(p=0.05)$.

\section{RESULTS AND DISCUSSION}

The results demonstrated that the ABA foliar spray treatment significantly mitigated the blossomend rot incidence in tomato plants grown under field conditions with different water stress levels (Figure 1). The blossom-end rot occurrence ranged from $2.5 \%$ to $30 \%$ among the treatments, and the irrigation deficit treatments reached the highest blossom-end rot incidence, when compared with the ABA treatments.

The treatment with foliar application of $500 \mathrm{mg} \mathrm{L}^{-1}$ of ABA and $100 \%$ of ETc restoration reached a blossom-end rot incidence of $2.5 \%$, similarly to what was observed in the control. These results indicate that there are no differences in the blossom-end rot incidence between the ABA and deionised water treatments, when plants are fully irrigated. The effects of the ABA treatment were visible when plants were under irrigation deficit. When plants were treated with $75 \%$ of ETc restoration and $500 \mathrm{mg} \mathrm{L}^{-1}$ of ABA foliar spray, the incidence of blossom-end rot reached $3 \%$, whereas, in plants with deionised water, the blossom-end rot incidence reached $18 \%$. Plants treated with $50 \%$ and $25 \%$ of ETc restoration and $500 \mathrm{mg} \mathrm{L}^{-1}$ of ABA foliar spray showed $5 \%$ of blossom-end rot incidence, in contrast with $30 \%$ for blossom-end rot with no ABA treatment.

The ABA treatment improved the Ca uptake into the fruit, during its growth and development, relatively to the water sprayed fruit at $100 \%$ of ETc restoration at $30 \mathrm{DAA}$ (Table 1).

Plants treated with $500 \mathrm{mg} \mathrm{L}^{-1}$ of ABA had the highest $\mathrm{Ca}$ concentration in the fruit tissue, when compared with all deionised water treatments. Although the Ca content among the ABA treatments had no statistical difference, the $25 \%$ of ETc restoration had the highest $\mathrm{Ca}$ concentration. In

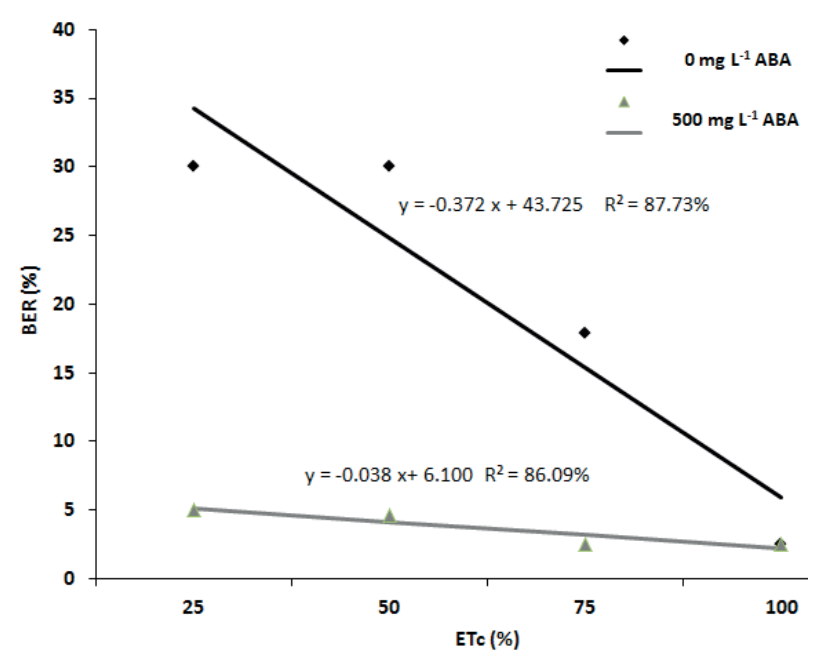

Figure 1. Incidence of blossom-end rot (BER) at 30 days after the anthesis, in tomato fruits grown under field conditions with four irrigation levels and sprayed weekly with abscisic acid (ABA) or water. 
contrast, plants treated with deionised water and $25 \%$ of ETc restoration had the lowest $\mathrm{Ca}$ concentration in the fruit tissues (Table 1).

The results demonstrated that treating the whole plant with ABA increased the Ca concentration in the distal end of the tomato fruits. These results are in accordance with previous studies, which showed that spraying ABA on the whole plant increases the Ca partition in the blossom-end region (Barickman et al. 2014, Freitas et al. 2014).

The Ca uptake is linked to the water absorption, and its uptake increases with high transpiration rates (Adams \& Ho 1993), and ABA promotes the stomata closure, thus decreasing the water flow and $\mathrm{Ca}$ content into the leaf (Freitas et al. 2014). It would be expected that the Ca content of the fruit tissue should reduce; nevertheless, the $\mathrm{Ca}$ content of the fruit tissues increases with a reduced leaf transpiration rate (Adams \& Ho 1993, Ho \& White 2005). These findings may be explained by the fact that plants treated with ABA had a lower stomatal conductance and, therefore, lower plant water loss, lower water movement into the leaves and increased water movement into the rapidly expanding fruit, thus reaching the blossom end (Freitas et al. 2011 and 2014).

The results showed that the $\mathrm{Ca}$ content increased when the water level decreased. The $\mathrm{Ca}$ fruit content of $500 \mathrm{mg} \mathrm{L}^{-1}$ of ABA foliar spray and $25 \%$ of ETc restoration was 3-fold high, when compared with the control. By contrast, the $0 \mathrm{mg} \mathrm{L}^{-1}$ of ABA foliar spray and $25 \%$ of ETc reduced the $\mathrm{Ca}$ concentration by $54 \%$. Plants treated with ABA and $50 \%$ of ETc restoration had the fruit $\mathrm{Ca}$ concentration

Table 1. Calcium concentration in the distal fruit tissue, at 15 and 30 days after the anthesis (DAA), in tomato grown under field conditions with four irrigation levels and sprayed weekly with abscisic acid (ABA) or water.

\begin{tabular}{rccc}
\hline \multicolumn{2}{c}{ Treatments } & \multicolumn{2}{c}{$\mathrm{Ca}\left(\mathrm{mg} \mathrm{g}^{-1}\right)$} \\
\hline ABA $\left(\mathrm{mg} \mathrm{L}^{-1}\right)$ & Etc $(\%)$ & $15 \mathrm{DAA}$ & $30 \mathrm{DAA}$ \\
\hline 0 & 100 & $1.16 \mathrm{a}^{*}$ & $0.41 \mathrm{~b}$ \\
500 & 100 & $0.98 \mathrm{a}$ & $0.73 \mathrm{a}$ \\
0 & 75 & $0.54 \mathrm{a}$ & $0.57 \mathrm{~b}$ \\
500 & 75 & $1.31 \mathrm{a}$ & $0.83 \mathrm{a}$ \\
0 & 50 & $1.14 \mathrm{a}$ & $0.60 \mathrm{~b}$ \\
500 & 50 & $1.02 \mathrm{a}$ & $0.93 \mathrm{a}$ \\
0 & 25 & $0.86 \mathrm{a}$ & $0.22 \mathrm{~b}$ \\
500 & 25 & $1.00 \mathrm{a}$ & $1.20 \mathrm{a}$ \\
\hline
\end{tabular}

* Means followed by the same letter between the ABA treatments are not significantly different, according to the Scott-Knott test $(\mathrm{p}=0.05)$. reaching more than 2.3 -fold, while the treatment with no ABA, in combination with $50 \%$ of ETc, increased the fruit Ca content by $46 \%$, if compared to the control (Table 1). The ABA foliar application, combined with $75 \%$ and $100 \%$ of ETc, increased the fruit $\mathrm{Ca}$ content by approximately $100 \%$ and $78 \%$, respectively, whereas $75 \%$ of ETc combined with deionised water increased the fruit $\mathrm{Ca}$ content by $39 \%$, and foliar spray with $500 \mathrm{mg} \mathrm{L}^{-1}$ of $\mathrm{ABA}$ increased the fruit $\mathrm{Ca}$ content by $78 \%$. The results demonstrated that there were no statistical differences in the fruit $\mathrm{Ca}$ concentration at 15 DAA, as well as in the leaf Ca concentration at 15 DAA (Table 2).

The ABA interferes with the Ca uptake and translocation to the shoot, by reducing the root resistance to water uptake, therefore influencing the ion uptake. In addition, the application of ABA increased the Ca concentration in arabidopsis cells (Murata et al. 2001) and Commelina communis (Staxén et al. 1999). The Ca partitioning into fruits is also affected by reduced irrigation. Sun et al. (2013) found an irrigation deficit partition into the fruit tissues. The fact that the $\mathrm{Ca}$ content increases due to the ABA application, as observed in the present experiment, supports this explanation.

No significant differences were observed in the leaf $\mathrm{Ca}$ accumulation, what corroborates previous results presented by Sánchez-Rodríguez et al. (2010), who concluded that there is no significant increase in the leaf $\mathrm{Ca}$ concentration in water stressed plants, when compared to full-irrigated plants, although its uptake decreased in plants under water stress.

Previous reports demonstrated that a weekly ABA foliar spray decreases the blossom-end rot

Table 2. Calcium concentration in fully expanded leaves of tomato plants grown under field conditions with four irrigation levels and sprayed weekly with abscisic acid (ABA) or water, at 15 days after the anthesis.

\begin{tabular}{ccc}
\hline \multicolumn{2}{c}{ Treatments } & Ca $\left(\mathrm{mg} \mathrm{g}^{-1}\right)$ \\
\cline { 1 - 2 } ABA $\left(\mathrm{mg} \mathrm{L}^{-1}\right)$ & Etc $(\%)$ & $30.62 \mathrm{a}^{*}$ \\
500 & 100 & $37.00 \mathrm{a}$ \\
0 & 100 & $32.42 \mathrm{a}$ \\
500 & 75 & $33.28 \mathrm{a}$ \\
0 & 75 & $29.76 \mathrm{a}$ \\
500 & 50 & $38.02 \mathrm{a}$ \\
0 & 50 & $30.09 \mathrm{a}$ \\
500 & 25 & $37.32 \mathrm{a}$ \\
\hline
\end{tabular}

* Means followed by the same letter between the ABA treatments are not significantly different, according to the Scott-Knott test $(\mathrm{p}=0.05)$. 
incidence (Freitas et al. 2014, Barickman et al. 2014). Our results indicate that the ABA reduced the blossom-end rot occurrence by increasing the $\mathrm{Ca}$ partitioning into distal fruit tissues, although the $\mathrm{Ca}$ concentration in the fruit cannot be considered as a primary or independent cause of blossom-end rot, because the $\mathrm{Ca}$ content in fruits with blossom-end rot symptoms can be equal or higher than in healthy fruits (Nonami et al. 1995, Saure 2005, Waterland et al. 2010). Normally, plants with a high rate of blossom-end rot have the lowest $\mathrm{Ca}$ concentration in the distal end of the fruit. The results of this study demonstrated that $500 \mathrm{mg} \mathrm{L}^{-1}$ of ABA foliar spray increased the Ca partitioning into the distal end, when compared with the treatment with no ABA. Plants treated with $\mathrm{ABA}$ had a higher $\mathrm{Ca}$ content in the distal end fruit tissue than control plants, as also observed by Freitas et al. (2011). Furthermore, when plants are under a mild stress, a momentary ABA synthesis is stimulated, what reduces gibberellins and enhances the Ca import, thus diminishing the blossom-end rot incidence rate (Saure 2005, Wang et al. 2012).

The blossom-end rot occurrence rate was high in plants under irrigation deficit and non-ABA treatments. These findings are in contrast with Sperry et al. (1996), who found that the soil moisture does not affect the blossom-end rot incidence, but are in concordance with Morales (2012) and Sun et al. (2013), who observed that the irrigation deficit affects the blossom-end rot occurrence. In addition, Morales (2012) concluded that, in plants under water stress, the blossom-end rot incidence reached about $90 \%$, in susceptive cultivars.

\section{CONCLUSIONS}

1. The application of abscisic acid improves the calcium uptake and its partitioning into tomato tissues, in irrigated plants;

2. The abscisic acid reduces the blossom-end rot incidence rate in tomato plants under water stress.

\section{REFERENCES}

ADAMS, P.; HO, L. Effects of environment on the uptake and distribution of calcium in tomato and on the incidence of blossom-end rot. Plant and Soil, v. 154, n. 1, p. 127132, 1993.

ASTACIO, M.; VAN IERSEL, M. Determining the effects of abscisic acid drenches on evapotranspiration and leaf gas exchange of tomato. HortScience, v. 46, n. 11, p. 15121517, 2011.

ATKINSON, C. Is xylem sap calcium responsible for reducing stomatal conductance after soil liming? Plant and Soil, v. 382, n. 1-2, p. 349-356, 2014.

BARICKMAN, T. et al. Foliar applications of abscisic acid decrease the incidence of blossom-end rot in tomato fruit. Scientia Horticulturae, v. 179, n. 1, p. 356-362, 2014.

BRASIL. Ministério da Agricultura e da Reforma Agrária. Departamento Nacional de Meteorologia. Normais climatológicas: 1961-1990. Brasília, DF: Ministério da Agricultura e Reforma Agrária, 1992.

COSTA, J. et al. Deficit irrigation as a strategy to save water: physiology and potential application to horticulture. Journal of Integrative Plant Biology, v. 49, n. 10, p. 14211434, 2007.

CUTLER, S. et al. Abscisic acid: emergence of a core signaling network. Annual Reviews of Plant Biology, v. 61, n. 1, p. 651-679, 2010.

DOORENBOS, J.; PRUITT, W. Guidelines for predicting crop water requirements. Rome: FAO, 1977.

FREITAS, S. T. de et al. Abscisic acid triggers whole-plant and fruit-specific mechanisms to increase fruit calcium uptake and prevent blossom-end rot development in tomato fruit. Journal of Experimental Botany, v. 62, n. 8, p. 2645-2656, 2011.

FREITAS, S. T. de et al. Calcium partitioning and allocation and blossom-end rot development in tomato plants in response to whole-plant and fruit-specific abscisic acid treatments. Journal of Experimental Botany, v. 65, n. 1, p. 235-247, 2014.

GEERTS, S.; RAES, D. Deficit irrigation as an on-farm strategy to maximize crop water productivity in dry areas. Agricultural Water Management, v. 96, n. 9, p. 1275-1284, 2009.

GOMES, L. A. et al. Recomendações de adubação para cultivos em ambiente protegido. In: RIBEIRO, A. C. Recomendações para o uso de corretivos e fertilizantes em Minas Gerais: $5^{\text {a }}$ aproximação. Viçosa: Comissão de Fertilidade do Solo do Estado de Minas Gerais, 1999.

HO, L. C.; WHITE, P. J. A cellular hypothesis for the induction of blossom-end rot in tomato fruit. Annals of Botany, v. 95, n. 4, p. 571-581, 2005.

JIANG, F.; HARTUNG, W. Long-distance signalling of abscisic acid (ABA): the factors regulating the intensity of the ABA signal. Journal of Experimental Botany, v. 59, n. 1, p. 37-43, 2008.

MORALES, R. G. F. Resistência ao déficit hídrico em famílias de tomateiro derivados de Solanum pennellii. 
2012. 93 f. Tese (Doutorado em Fitotecnia) - Universidade Federal de Lavras, Lavras, 2012.

MURATA, Y. et al. Abscisic acid activation of plasma membrane $\mathrm{Ca}^{2+}$ channels in guard cells requires cytosolic NAD (P) $\mathrm{H}$ and is differentially disrupted upstream and downstream of reactive oxygen species production in abi1-1 and abi2-1 protein phosphatase $2 \mathrm{C}$ mutants. The Plant Cell, v. 13, n. 11, p. 2513-2523, 2001.

NONAMI, H. et al. Blossom-end rot of tomato plants may not be directly caused by calcium deficiency. Acta Horticulturae, v. 395, n. 1, p. 107-114, 1995.

SÁNCHEZ-RODRÍGUEZ, E. et al. Study of the ionome and uptake fluxes in cherry tomato plants under moderate water stress conditions. Plant and Soil, v. 335, n. 1-2, p. 339-347, 2010.

SAURE, M. Calcium translocation to fleshy fruit: its mechanism and endogenous control. Scientia Horticulturae, v. 105, n. 1, p. 65-89, 2005.

SAURE, M. Why calcium deficiency is not the cause of blossom-end rot in tomato and pepper fruit: a reappraisal. Scientia Horticulturae, v. 174, n. 1, p. 65-89, 2014.

SCHACHTMAN, D.; GOODGER, J. Chemical root to shoot signaling under drought. Trends in Plant Science, v. 13 , n. 6 , p. $281-287,2008$.
SPERRY, W. et al. Soil moisture and cultivar influence cracking, blossom end-rot, zippers and yield of staked fresh market tomatoes. HortTechnology, v. 6, n. 1, p. 21-24, 1996.

STAXÉN, I. et al. Abscisic acid induces oscillations in guard-cell cytosolic free calcium that involve phosphoinositide-specific phospholipase C. Plant Biology, v. 96, n. 4, p. 1779-1784, 1999.

SUN, Y. et al. Comparative effect of partial root-zone drying and deficit irrigation on incidence of blossomend rot in tomato under varied calcium rates. Journal of Experimental Botany, v. 64, n. 7, p. 2107-2116, 2013.

SUZUKI, K. et al. Localization of calcium in the pericarp cells of tomato fruits during the development of blossomend rot. Protoplasma, v. 222, n. 3, p. 149-156, 2003.

WANG, Y. et al. Comparative effects of deficit irrigation and alternate partial root-zone irrigation on xylem $\mathrm{pH}$, $\mathrm{ABA}$ and ionic concentrations in tomatoes. Journal of Experimental Botany, v. 63, n. 5, p. 1907-1917, 2012.

WATERLAND, N. et al. Abscisic acid application enhances drought stress tolerance in bedding plants. Hortscience, v. 45, n. 3, p. 409-413, 2010.

WHITE, P. The pathways of calcium movement to the xylem. Journal of Experimental Botany, v. 52, n. 358, p. 891-899, 2001. 